\title{
Much Ado About Nothing: The Case of the Nigerian Microfinance Policy Measures, Institutions and Operations
}

\author{
B. O. Iganiga \\ Department of Economics, Ambrose Alli University, Ekpoma, Nigeria \\ E-mail: beniga3@yahoo.co.uk
}

KEYWORDS Community bank; credit delivery; microfinance

\begin{abstract}
From the literature, it has been observed that there exist a huge untapped potential for financial intermediation at the micro and rural levels of the Nigerian economy. Attempts by the government in the past to fill this gap, through supply - driven creation of financing institutions and schemes have failed due to high operating cost, repayment problem, weak refinancing facilities, client apathy and drop out among others. To this end, the paper suggested some success imperatives including group delivery methodology, efficient Management Information System (MIS), involvement of clients and intensive use of microfins and monitoring among others to achieve the stated microfinance policy objectives within the ambit of the Millennium Development Goal (MDGs) by 2015 .
\end{abstract}

\section{INTRODUCTION}

Robust economic growth cannot be achieved without putting in place well focused programmes to reduce poverty through empowering the people by increasing their access to factors of production, especially credit. The latent capacity of poor for entrepreneurship would be signifi-cantly enhanced through the provision of micro-finance services to enable them engage in economic activities and be more self-reliant, increase employment opportunities, enhance household income, and create wealth (Iweala, 2005).

Microfinance is about providing financial services to the poor who are traditionally not served by the conventional financial institutions. Three features distinguish microfinance from other formal financial products. These are: (i) the smallness of loans advanced and/or savings collected, (ii) the absence of asset-based collateral, and (iii) simplicity of operations (Ogbunaka, 2003).

Over the years, microfinance has emerged as an effective strategy for poverty reduction. Across developing countries, micro, small and medium enterprises are turning to Microfinance Institutions (MFIs) for an array of financial services. Microfinance is acknowledged as one of the prime strategies to achieve the Millennium Development Goals (MDGs). Access to sustainable financial services enable owners of micro enterprises to finance income, build assets, and reduce their vulnerability to external shocks. Access to financial services enable poor households to move from everyday for survival to planning for the future, investing in better nutrition, their children's education and health and empowering women socially (Ehigiamusoe, 2005).

In Nigeria, micro-financing is not a new phenomenon as evidenced by such cultural economic activities as "Esusu", "Adashi", "Otataje", etc, which were practiced to provide funds for producers in our rural communities. What is current however, is the effort of governments in Nigeria to modernize micro-financing in rural and urban communities to improve the productive capacity of the rural and urban poor, enhance their economic standing which alleviates the level of the national economy.

After failed trials in Directorate of Food, Road and Rural Infrastructure (DFRRI), Rural Banking by commercial Banks and even People's Bank programme, the government of the Federal Republic of Nigeria took the bull by the horns by enacting legislation for the establishment of community banks (now microfinance institution). To complement government efforts, over the years, a lots of NGOs has formally been licenced to operate as micro finance institutions. Some existing NGO microfinance institutions were transformed and Universal Banks were encouraged to engage in microfinance services of recent, microfinance banks regulation and supervisory guidelines were inaugurated.

Given this background, this paper is poised to examine the Nigerian microfinance policy measures, institutions and operation over the 
years. Evaluate the effectiveness of these policies and institutions in providing the needed sucour to their target group and the emerging challenges.

\section{CONCEPTUAL ISSUES}

Microfinance is the supply of loans, savings and other basic financial services to the poor. These owners of micro and small enterprises require a diverse range of financial instruments to meet working capital requirement, build assets, stabilize consumption, and shield themselves against risks (Ehigiamusoe, 2005). Financial services include working capital loans, consumer credit, savings, pensions, insurance, and money transfer services. In practice, microfinance is much more than disbursement, management and collection of little bits of loans.

In a more comprehensive style, Ehigiamusoe, 2005 , stressed that microfinance refers to "flexible processes and structures by which financial services are delivered to owners of microfinance enterprise on a sustainable basis". Microfinance recognizes the peculiar challenges of micro enterprises and of their owners. It recognizes the inability of the poor to provide tangible collateral and therefore promotes collateral substitution. Disbursement and repayment are structured to suit credit need and cash flow pattern of small businesses (Aderibigbe, 2001).

Kimotha, 2005 defined microfinance simply as the provision of very small loans (micro credit) to the poor, to help them engage in new productive business activities and/or to grow/ expand existing ones. However, overtime, microfinance has come to include a broader range of services. These include mainly credit, savings opportunities, insurance and money transfer, as practitioners came to realize that the poor, who lacked access to traditional formal financial institution, needed and required a variety of financial products to achieve meaningful improvement in their business activities.

While microfinance refers to loans, savings opportunities, insurance, money transfers and other financial products targeted at the poor, micro-credit refers specially to small loans. The average loan size varies from country to country, but in most cases, the average loan is equivalent to $\$ 120.0-$ 150.0 in the respective currency. For example, in Philippines, the average loan size is $\$ 124.0$.

Microfinance is not charity despite its appellation as "poverty lending". Primarily, microfinance seeks to create access to credit for the poor who ordinarily are locked out of financial services in the formal financial market for reason of their poverty, that is lack of command over assets. It therefore places obligation on the borrowers for proper utilization and complete repayment of borrowed amounts even at commercial interest rates (Kpakol, 2005).

From the literature, three (3) features distinguished microfinance from other formal financial products. These are:

(a) the smallness of the loans advanced or savings collected.

(b) The absence of asset based collateral and

(c) Simplicity of operations.

Given these characteristics, microfinance institution (MFI) has come to be defined as any institution that provides credit and other financial services to the low income entre-preneurs who are traditionally not served by the conventional/formal financial institutions.

Microfinance is not new especially to us in Africa. In our societies and history, we come across schemes and social arrangements which enable people to pool their financial resources for onward distribution to cooperating and needy individuals. Ready examples includes "adashi" and several variants of "esusu". Nigerian microfinance institutions have also integrated best practices of traditional schemes into their operational procedures.

\section{A REVIEW OF MICROFINANCE POLICY MEASURES AND INSTITUTIONS IN NIGERIA}

In this section, an attempt shall be made to $\mathrm{X}$-ray some policy measures and institutions that have been put in place by the government and non-governmental organizations (NGO) to facilitate the operation of microfinance scheme in Nigeria.

\section{Microfinance Policy}

\section{a. Microfinance Policy Measures}

In Nigeria, the formal financial system provides services to about $35 \%$ of the economically active population, while the remaining $65 \%$ are excluded from access to financial services. These $65 \%$ are often served by the informal financial 
sector, through Non-Governmental Organisation Microfinance Institutions (NGO - MFIs), money leaders, friends, relatives, and credit unions. The non-regulation of the activities of some of these institutions has serious implications for the Central Bank of Nigeria's (CBN) ability to exercise one aspect of its mandate of promoting monetary stability and a sound financial system.

A microfinance policy which recognizes the existing informal institutions and brings them within the supervisory purview of the CBN would not only enhance monetary stability, but also expand the financial infrastructure of the country to meet the financial requirements of the Micro, Small and Medium Enterprises (MSMEs). Such a policy over the years have been aimed at creating a vibrant microfinance sub-sector that would be adequately integrated into the mainstreams of the national financial system and provide the stimulus for growth and development.

Over the years, the federal ministry of finance in conjunction with the Central Bank of Nigeria $(\mathrm{CBN})$ have formulated various policies aimed at stimulating the operation of microfinance institutions in Nigeria.

\section{Nigeria Microfinance Policy Strategies}

Some of the notable microfinance policy strategies conjured by ministry of finance and Central Bank of Nigeria (CBN) over the years include:

(i) License and regulate establishment of Microfinance Banks (MFBs).

(ii) Promote the establishment of NGO-based microfinance institutions.

(iii) Promote the participation of government in microfinance industry by encouraging states and local governments to devote at least one percent of their annual budgets to micro credit initiatives administered through MFBs.

(iv) Promote the establishment of institutions that support the development and growth of microfinance service providers and clients.

(v) Strengthen the regulatory and supervisory framework for MFBs.

(vi) Promote sound microfinance practice by advocating professionalism, transparency and good governance in microfinance institutions.

(vii) Mobilize domestic savings and promote the banking culture among low-income groups.

(viii) Strengthen the capital base of the existing microfinance institutions. (ix) Broaden the scope of activities of microfinance institutions.

(x) Collaborate with donors, coordinate and monitor donor assistance in microfinance in line with the provisions of microfinance policy.

(xi) Increase in the capital base of community banks (now microfinance institutions) from $\mathrm{N} 250,000$ to $\mathrm{N} 20 \mathrm{~m}$.

\section{b. Microfinance Policy Targets}

The targets of the above policy measures are as follows:

1) To cover the majority of the poor but economically active population by 2020 thereby creating millions of job and reducing poverty.

2) To increase the share of micro-credit as a percentage of total credit to the economy from 0.9 percent in 2005 to at least 20 percent in 2020; and the share of micro-credit as a percentage of GDP from 0.2 percent in 2005 to at least 15 percent in 2020 .

3) To promote the participation of at least two thirds of the states and local governments in micro-credit financing by 2015 .

4) To eliminate gender disparity by improving women's access to financial services by $5 \%$ annually; and

5) To increase the number of linkages among universal banks, development banks, specialized finance institutions and microfinance banks by $10 \%$ annually.

\section{c. Policy Objectives}

The specific objectives of microfinance policy over the years include:

(1) Make financial services accessible to a large segment of the potentially productive Nigerian population which otherwise would have little or no access to financial services;

(2) Promote synergy and mainstreaming of the informal sub-sector into the national financial system;

(3) Enhance service delivery by microfinance institutions to Micro, Small and Medium Entrepreneurs;

(4) Contribute to rural transformation, and

(5) Promote linkage programmes between universal/developments banks; specialized institutions and microfinance banks.

Given these myriads policy objectives, to 
what extent have they been realized? An examination of this fact/puzzle forms the main thrust of the paper. Before attempting this evaluation, a brief discussion of the various institutions involved in microfinancing is imperative.

\section{PARTICIPATING INSTITUTIONS IN MICROFINANCE ACTIVITIES IN NIGERIA}

The practice of microfinance in Nigeria can be categorized thus,

1. Informal/Traditional microfinance institutions

2. Formal/Modern microfinance institutions

\section{Informal/Traditional Microfinance Institutions}

The practice of microfinance in Nigeria is culturally rooted and dates back several centuries. The traditional microfinance institutions provide access to credit for the rural and urban, low income earners. They are mainly the informal SelfHelp Groups (SHGs) or rotating Savings and Credit Associations (ROSCAS) type. Other providers of microfinance services include savings collectors and co-operative societies. The informal financial institutions generally have limited outreach due primarily to paucity of loanable funds (Agaifa, 2006).

In order to enhance the flow of financial services to Nigeria's rural areas, government has, in the past, initiated a series of publicly - financed micro/rural credit programmes and policies targeted at the poor. This led to the establishment of formal microfinance institutions.

\section{Formal/Modern Microfinance Institutions}

These include:

\section{a. Universal Banks}

Universal banks currently engaged in microfinance services, either as an activity or product do set up a department/unit for such services and such unit is subject to the provisions of the MFBs regulatory and supervisory guidelines.

\section{b. Community Banks (Microfinance Banks)}

All licensed community banks in Nigeria that met CBN guidelines have been transformed to Microfinance Bank. There are two categories of Microfinance Banks (MFBs).

(i) Micro-Finance Banks (MFBs) licensed to operate as a unit. These are hitherto community banks licensed to operate branches and/ or cash centres subject to meeting the prescribed prudential requirements and availability of free funds for opening branches/cash centres. The minimum paid-up capital, this category of banks is N20 million for each branch. The branching should be gradual within a local council before it spreads to other local councils and state.

(ii) Micro-Finance Banks (MFBs) licensed to operate in a state.

These are MFBs licensed to operate in all parts of the state at once without recourse to gradual coverage (spread) as in unit MFBs. Branches are opened subject to meeting the prescribed prudential requirements and availability of free funds. The minimum paid-up capital for this category of banks is N1 billion.

\section{Non-Governmental Organisation Micro Finance Institutions (NGO - MFIS)}

The present policy in Nigeria recognizes the existence of credit only membership - based microfinance institutions under the supervisory purview of the Central Bank of Nigeria, such institutions engaged in the provision of microcredit to their targeted population and forbidden from mobilizing deposits from the general public. The registered NGO - MFIs are required to forward periodic returns on their activities to the CBN. Lift above poverty organisation (LAPO) in Benin City is an example of NGO - MFIs. NGO MFIs that wish to obtain the operating license of a microfinance bank are required to meet the specified provisions as stipulated in the regulatory and supervisory guidelines.

Special microfinance schemes operated by some state governments fell under this category.

\section{Public Sector Poverty Alleviation Agencies}

The MFB policy recognizes the roles of public sector MFIs and poverty alleviation agencies such as the National Poverty Eradication Programme (NAPEP) and Small and Medium Enterprises Equity Scheme (SMEEIS) in the 
development of the sub-sector. Such agency performs the following functions.

(i) Provision of resources targeted at difficultto-reach clients and the poorest of the poor; (ii) Capacity building;

(iii) Development of MFIs' activities nationwide;

(iv) Collaborating/partnering with other relevant stakeholders; and

(v) Nurturing of new MFIs to a sustainable level.

\section{Special Microfinance Schemes}

In Nigeria today, some governmental agencies across the various tiers of government operate special credit schemes for traders, farmers, young school leavers, graduates and artisans. These are credit outlets that may not be registered and hence not supervised by CBN. They are directly under the control of the government agency that midwives them.

\section{Donor Agencies}

Donor agencies offer free or subsidized funds, donations or technical assistance for the development of the microfinance industry in Nigeria. They include bilateral and multilateral institutions, NGO and missionaries with a Propoor orientation. The services provided by donor agencies include grants, donations, technical assistance, etc.

The donor agencies, in conducting their microfinance activities complied with the relevant provisions of this policy. The target clients for donors' support may include; MFIs, NGO, regulatory, and other relevant agencies. However, for the purpose of leveraging the evolving microfinance initiative, donors are expected to direct most of their assistance to licensed MFIBs to ensure an orderly resource injection, transparency and synergy.

Once again, given these numbers of microfinance institutions and agencies, is the existing potential for financial inter-mediation at the micro and rural levels in the Nigerian economy fully tapped? The answer to this question forms the main crux of the next subsection.

\section{STYLIZED FACTS ON THE OPERATION OF MICROFINANCE PROGRAMME IN NIGERIA}

The practice of microfinance in Nigeria is culturally rooted and dates back several centuries. The traditional microfinance institution provide access to credit for the rural and urban, low-income earners. They are mainly the informal Self-Help Groups (SHGs) or Rotating Savings and Credit Associations (ROSCAS) types. Other providers of microfinance services include saving collectors and co-operative societies. The informal financial institutions generally have limited outreach due primarily to paucity of loanable funds.

In order to enhance the flow of financial services to Nigeria's rural areas, successive governments in Nigeria have in the past, initiated a series of publicly - financed micro/rural credit programmes and policies targeted at the poor. Notable among such programmes are:

1. Rural Banking programme.

2. Sectoral Allocation of Credits, Concessionary Interest Rate, and the Agricultural Credit Guarantee Schemes (ACGS) in 1977.

3. Establishment of the Nigerian Agricultural and Cooperative Bank Limited (NACB), in 1973.

4. Introduction of National Directorate of Employment (NDE).

5. Establishment of the Nigerian Agricultural Insurance corporation (NAIC) in 1988.

6. People Bank of Nigeria (PBN) and Community Banks (Now Microfinance Banks) was established in 1989 and 1990 respectively.

7. Family Economic Advancement Programme (FEAP) was initiated.

8. The Nigerian Bank for Commerce and Industry (NBCI) was established in 1973.

9. In year $2000, N A C B$ and PBN and FEAP were merged to form the Nigerian Agricultural Cooperative and Rural Development Bank Limited (NACRDB).

10. National Poverty Eradication Programme (NAPEP) was launched in 2003.

11. Small and Medium Enterprises Equity Investment Scheme (SMEEIs) was initiated of recent.

Microfinance Services, particularly, those sponsored by government, have adopted the traditional supply - led subsidized credit approach mainly directed to the agricultural sector and non farm activities, such as trading, tailoring, weaving, blacksmithing, agro-processing and transportation. Although the services have resulted in an increased level of credit disbursement and gains in agricultural production and other activities, the effects were short-lived due to the unsustainable nature of the programme.

Since the 1980s, Non-Governmental Organiza- 
Table 1: Major microfinance institutions and schemes in Nigeria

\begin{tabular}{llllll}
\hline Institutions & Year of Est. & Objectives & Type of Inst. & Ownership & Statue \\
\hline NACB/NACRD & 1973 & Rural financing & DFI & Government & Merged \\
B & 1973 & Rural financing & DFI & Government & Merged \\
NBCI/BOI & 1989 & Rural financing & DFI & Government & Merged \\
PBN/NACRDB & 1990 & Commercial & Commercial & Private & Existing \\
CBS/Microfin & & & & & \\
\hline Schemes & & & & & \\
ACGS & 1977 & Provide fund for Agr. & Agric finance & Government & Merged \\
NDE & 1987 & Create employment & Public & Government & Existing \\
NAIC & 1988 & Insure Afric Product & Public & Government & Existing \\
FEAP & 1991 & Reduce poverty & Public & Government & Merged \\
NAPEP & 2002 & Reduce poverty & Public & Government & Existing \\
NEEDS & 2004 & Reduce poverty & Public & Government & Existing \\
SMEEIS & 2004 & Reduce poverty & Fund & Government & Existing \\
\hline
\end{tabular}

Source: Financial Markets in Nigeria, CBN Publication, 2005.

Some derived from CBN Reports.

Note $:$ DFI $=$ Development Finance Institution

NEEDs = National Economic Empowerment Development Strategies

NAPEP $=$ National Poverty Eradication Programme

NAIC $=$ Nigeria Agricultural Insurance Corporation

ACGS = Agricultural Credit Guarantee Schemes

SMEEIS $=$ Small and Medium Enterprises Equity Investment Scheme

tions (NGOs) have emerged in Nigeria to champion the cause of the micro and rural entrepreneurs, with a shift from the supply - led approach to a demand-driven strategy. The number of NGOs involved in microfinance activities has increased significantly in recent times due to the inability of the formal financial sector to provide the services needed by the low income groups and the poor, and the declining support from development partners amongst others.

The NGOs are charity, capital lending and credit only membership based institutions. They are generally registered under the "trusteeship Act" as the sole package or part of their charity and social programmes of poverty alleviation. A CBN survey of MFIs in 2005 identified 180 registered MFIs in Nigeria. Their operations increased tremendously of late interms of size, branch expansion, staffing, saving and credit levels. 96 institutions that responded to the CBN survey had between then savings of about N99.4 million and outstanding credit of about N649.6 million (CBN, EFR, 2006). The NGOs obtain their funds, grants, fees, interest on loans and contributions from their members. However, they have limited outreach due, largely to unstable sources of funds.

From the foregoing, it could be observed that there are significant business transaction in the financial subsector, and yet we also know that much of Nigeria's microfinance needs are still not met and that microfinance need are high and continue to increase

\section{Assessment of Performance Based on Out - Reach Analysis of Major Microfinance Institutions and Schemes}

For the purpose of this analysis, emphasis will be the major microfinance institutions and schemes that have been existence for quite some time.

\section{a. Nigerian Agricultural and Co-operative Bank Limited (NACB/NACRDB)}

The Nigerian Agricultural and Co-operative Bank Limited (NACB) was established in 1973. NACB is owned $60 \%$ by the federal government of Nigeria and $40 \%$ the Central Bank of Nigeria. NACBs objectives include the promotion of agricultural production and rural development; assisting in the improvement of the income and quality of life of rural dwellers through the granting of small and medium term loans.

\section{Credit Delivery}

NACB delivers credit to the agricultural sector of the economy at concessionary interest rates. This is carried out through the provision of loans to individual farmers, co-operative organizations limited companies, and state and federal government 
Table 2: Distribution of microfinance banks (community bank) in Nigeria

\begin{tabular}{|c|c|c|c|c|}
\hline & State/Zone & $\begin{array}{c}\text { Cbn } \\
\text { Licensed }\end{array}$ & States/Zones & $\begin{array}{c}\text { Cbn } \\
\text { Licensed }\end{array}$ \\
\hline \multirow{8}{*}{1} & South East Zone & & South South Zone & \\
\hline & Abia State Chapter & 19 & River State Chapter & 10 \\
\hline & Abambra State & 81 & Cross River State & 14 \\
\hline & Imo State Chapter & 37 & Bayelsa State Chapter & 1 \\
\hline & Ebonyi State Chapter & 6 & Edo State Chapter & 20 \\
\hline & Enugu State & 22 & Akwa Ibom State & 7 \\
\hline & & & Delta State Chapter & 22 \\
\hline & & 165 & & 74 \\
\hline \multirow[t]{9}{*}{2} & North East Zone & & North West Zone & \\
\hline & Bauchi State Chapter & 6 & Sokoto State Chapter & 4 \\
\hline & Adamawa State & 7 & Zamfara State & 3 \\
\hline & Gombe State & 3 & Kaduna State Chapter & 6 \\
\hline & Borno State & 2 & Katsina State Chapter & Nil \\
\hline & Yobe State & 2 & Kebbi State Chapter & 6 \\
\hline & Taraba State & 2 & Kano State Chapter & 5 \\
\hline & & & Jigawa State Chapter & 1 \\
\hline & & 22 & & 25 \\
\hline \multirow[t]{8}{*}{3} & South West Zone & & North Central Zone & \\
\hline & Lagos State Chapter & 39 & Kwara State Chapter & 15 \\
\hline & Ogun State Chapter & 44 & Kogi State Chapter & 23 \\
\hline & Oyo State Chapter & 42 & Benue State Chapter & 7 \\
\hline & Osun Chapter & 26 & Plateau State Chapter & 7 \\
\hline & Ekiti State Chapter & 18 & Niger State Chapter & 7 \\
\hline & Ondo State Chapter & 17 & Nassarawa State & Nil \\
\hline & & & FCT, Abuja Chapter & 6 \\
\hline & . & 186 & & 65 \\
\hline
\end{tabular}

Source: Compiled by Author.

agencies. Although the number of loan outstanding during the period of existence, however, NACB had N3.8 billion loan outstanding in 1994 (see Appendix) in addition the number of agricultural projects that were granted loans by NACB increased from 2,446 in 1990 to 6,286 in 1994 . This represented a $157 \%$ growth in the number of loan approval by the Bank within 1990-1994. Similarly, the population served by the bank increased by $13.22 \%$ during the period. In addition, women accounted for only $1.73 \%$ of the population served by NACB as at 1999 . From 1995 - 1999, the NACB ran aground with outstanding loan of N3 billion unpaid and its activities was at its lowest ebb (se Appendix, Table A). This led to its emergence with NBC

\section{b. Nigerian Bank for Commerce and Industry (NBCI now BOI)}

Nigerian Bank for Commerce and Industry (NBCI) was established in 1973 for the provision of financial services, such as equity investment and granting of loans and guarantees to indigenous enterprises in commercial and manufacturing activities. NBCI, is owned $60 \%$ by the federal government and $40 \%$ by the Central Bank of Nigeria.

NBCI does not take deposit from the general public in any form. Funding has traditionally relied on government subventions, concessional loans from multilateral financial institutions and inter-bank borrowing. However, the Bank's clientele base increased by $212 \%$ within ten years from 259 clients in 1984 to 809 clients in 1994 (see Appendix). NBCI unlike NACB serves corporate organizations and small-scale manufacturers and not individuals.

\section{Credit Delivery}

The $212 \%$ growth in NBCI clientele from 259 to 809 also represented the growth in the number of loans granted during 1985 to 1994. Also, the number of outstanding loans increased from $208 \%$ to 798 during the same period (see Appendix). However, since 1995, there has been a sharp drop in the population served by NBCI. This was perhaps as a result of competition from the new generation commercial and merchant 
banks, dwindling funding resources and recession that hit the nation's small-scale manufacturers -which constituted NBCI's clientele base in the 1990s. Furthermore, the establishment of the National Economic Reconstruction Fund for providing finance to medium and small scale manufacturing enterprises appears to have duplicated the functions of NBCI in recent years and has made NBCI to have less impact among existing small manufacturers or new entrants into the manufacturing sector.

Following the dismal performance of NBCI in late 1990s, NBCI was merged with NIDB and NERFUND to form the new "Bank of Industry" (BOI) in 2000 with a recapitalisation of N50 billion whose activities who are yet to be well documented for proper appraisal.

\section{c. People's Bank of Nigeria (PBN now NACRDB)}

People's Bank of Nigeria (PBN) was established in 1989 for the provision of financial services such as savings and granting of credit facilities to the less privileged members of the Nigeria societies. In view of its policies of providing banking services to the remote area of the country, PBN draws its customers largely from the informal sector. PBN is $100 \%$ owned by the federal government of Nigeria and about $99.9 \%$ of its loanable funds derived from the three tiers of government.

\section{Credit Delivery}

From inception, the loans delivery rate of PBN has been low. In 1989, it stood at 625 in 1989. It rose to 3.917 in 1991, before it declined by $96.7 \%$ to 131 in 1994 (see Appendix). The economic recession and the low consumer demand which impacted adversely on general commerce as well as the need to contain the growth of bad loans were responsible for the decline in the number of credit sanctions during the period the bank existence. The number of loans outstanding fluctuated from year to year. However, only 53 loans were recorded as outstanding for 1993 and decreased to all time decrease of 25 in 1998.

There is no information regarding the clientele/flow -of funds between the rural and urban area and urban area and Sectoral distribution of credit during the period of its existence. However, women contributed only $2.01 \%$ of PBN clientele in 1998.
Due to the poor performance of PBN, in loans delivery, the bank was formally merged with NACB and FEAP to form the Nigerian Agricultural Cooperative and Rural Development Bank (NACRDB) limited on the $11^{\text {th }}$ of October, 2000 with a recapitalisation of N50 billion.

The new bank's primary role is grass root funds mobilisation and credit delivery. Consequently, in 2002, the sum of N2.13 billon was approved for 26,942 clients out of a total of 28,422 applicants who applied for an estimated N2.90 billion. In 2003, the sum of N1.045 billion was approved for disbursement to eligible customers in the first quarter of the year. As at the end of July 2003, the total of N2,916 billion had been approved by the bank for disbursement to eligible customers.

In spite of the emergence of these banks, the activities of NACRDB still remain restricted to the few urban centres with a negligible numbers of women as clientele (see Iganiga, 2006).

\section{d. Community Bank/Microfinance Banks}

Community banks are commercial entities that are expected to be profitable and self-sustaining. They engage in deposit mobilisation among the members of their community. Community banks started operation in Nigeria with the appearance of Kaduna Community Bank in December 1990.

According to the report of the National Board for Community Banks, the Clientele of CBs increased from an average of 1,546 in 1990 to 9,898 in 1994 i.e. over $60 \%$ increase (see Appendix). Similarly, the number of serving deposit accounts grew from an average of 1,773 in 1990 to $4,580(258 \%)$ by 1994 year end. This is by no means a mean achievement which could be accounted for by its grass root level and the distress syndrome that characterized other financial institutions then.

By 1995, there emerged 1355 community banks with provision licence issued by the National Board for Community Banks (NBCB). This number declined to 774 functional banks as a result of poor management, lack of training and insufficient supervision. In 2000, supervision of community banks was granted to the CBN by legislation. As at 2004, a total of $634 \mathrm{CBs}$ have been granted CBN final licenses.

During the first quarter of 2007 the capital base of community banks was reviewed from N5m to $\mathrm{N} 20 \mathrm{~m}$, the deposit of CBs were issued by NDIC 
and their activities were placed under the strict super vision of CBN for them to intermediate in microfinance programme effectively. 634.

The CBN Licensed Microfinance Banks are

Given the above Distribution in rural and urban areas, Microfinance banks have the widest reach to the grassroot poor producers in Nigeria.

\section{Credit Delivery}

CBs loans granted to clients increased from an average of 22 in 1991 to 5.367 in 1994 (Appendix) while the loans portfolio per community bank increased from average of N9 million in 1990 to N31 million in 1996 (Table Appendix). In addition, the number of loan outstanding per bank during the period increased from the average of 107 in 1990 and peaked at an average of 2,500 in 1992 and decline to an average of 154 in 1993. Furthermore, CBs were able to increase their credit base from $0.74 \%$ of the rural population served to $24.35 \%$ in 1994 , with outstanding loans per staff averaging N37,639 (see Appendix). Also, women accounted for $34.64 \%$ of CBs clientele base as at 1994 (see Appendix). This is more than three times the percentage of women by its nearest rival PBN.

As at the end of 2004, the micro-finance intermediation activities of community banks is as shown thus;

(a) Total mobilized deposits $=$ N21.4 billion

(b) Asset base = N34.2 billion

(c) Loans and Advances = N11.4 billion

The various poverty alleviation schemes including National Directorate of Employment (NDE), Family Economic Advancement Programme (FEAP), National Poverty Eradication Programme (NAPEP) and National Economic Empowerment and Development Strategy (NEEDS) to mention a few aimed at achieving the United Nation's Millennium Development Goals (MDGs) by 2015 required these microfinance institutions for success.

The success of these programmes and projects for advancement of the MDGs are linked with the successful funding of the various activities by the financial services of these microfinance institutions. The failure of these institutions means failure of these programmes among other factors. Thus, the non-performance of these schemes could be understood to a greater extent, (Ukeje and Amoo, 2005).

From the foregoing, it could be observed that the sampled microfinance institutions and schemes had not performed to expectation except community banks now microfinance institutions. This has left the large resources in the rural and semi-urban areas untapped and thus, exacerbated the level of poverty in these areas.

\section{CHALLENGES OF MICROFINANCING AND SUCCESS IMPERATIVES}

One of the acknowledged Eleven Principles of Microfinance is building of institutions which deliver financial services to the poor in an efficient manner and on a sustainable basis. It is only efficient institutions that can reach large number of people thereby making substantial impact on poverty.

To achieve sustainability and scale, microfinance institutions and authorities must device strategy to effectively address the six challenges of microfinance. These are:

(i) High Operating Cost: Small Units of services pose the challenges of high operating cost, several loan applications to be processed, numerous accounts to be managed and monitored, and repayment collections to be made from several locations especially in rural communities.

(ii) Repayment Problem: Loan delinquency is a major threat to institutional sustainability; it is the deadly "virus" which afflicts MFIs. Delinquency demoralizes staff and deprives beneficiaries of valuable services. Delinquency is a symptom of poor leadership. This has accounts for the failure of most MFIs and schemes in Nigeria.

(iii) Inadequate Experienced Credit Staff: Micro financing is more than dispensing loans. To be viable, MFIs require experienced and skilled personnel. As a young and growing industry, there is a dearth of experienced staff in planning, product development and effective engagement with clients. Most credit staff of MFIs in Nigeria are on their first jobs and majority are school leavers. This deficiency limits expansion and institutional performance.

(iv) Lack of RE-financing Facilities: MFIs in Nigeria are not-for-profit entities with donors as sources of funds. Grants are hardly adequate to meaningfully scale-up out-reach. Emerging development issues such as HIV/AIDs and environmental degradation are attracting attention of donor agencies. Non-profit status of MFIs 
inhibits effective engagement with financial institutions like the universal banks.

(v) Client Apathy and Drop-out: Improper client services and delivery strategies could lead to client drop-out. Most pro-poor MFIs lose up to $20 \%$ of their client base annually. High dropout rate increases cost as old clients who require little training are lost.

(vi) Internal Control Challenge: Large transactions and informal operational approach pose serious internal control challenge. Operational procedures could be breached at disbursement and collection points. High cash transaction which is a feature of microfinancing is a source of temptation for fraudulent practices.

\section{SUCCESS IMPERATIVES}

Microfinance institutions desiring to be sustainable, delivering appropriate services to a large number of clients, and doing so with excellent repayment performance, must pay attention to the following success imperatives.

(i) Group Delivery Methodology: A common feature of microfinance is group delivery methodology. Members are assisted and encouraged to organize into self-selecting credit groups. Membership of such groups ranged between five and sixty. Groups could be formed along commonality of business activities or location of residence or business.

Group methodology reduces cost of lending. Several visits to individuals' homes for disbursement and collections are reduced to few visits to group meetings. Also, group lending aids credit discipline and good repayment performance. Group members exert tremendous peer pressure on each other to perform.

(ii) Efficient Management Information System (MIS): Accurate and timely information is needed for planning and monitoring. Automated MIS is most preferred as it is fast, accurate and very efficient. It enhances staff productivity as it relieves credit offices of manual processing thereby freeing their time to recruit more clients. Where MIS is manual, it should be simple and transparent.

(iii) Intensive Monitoring: Intensive monitoring is the effective response to repayment problem and internal control challenge. Effective monitoring strategy consists of:

3 detail and clear operational procedures and monitoring check lists
4 availability of adequate monitoring staff. These are Area and Divisional Managers who are solely charged with the responsibility of ensuring that breaches of procedures are prevented, detected, corrected, and where necessary promptly sanctioned, and

5 monitoring activities should be extended beyond branch operations to activities at the credit group level.

(iv) Involvement of Clients: Service users should not be seen as faceless customers of formal financial institutions who are identified by their account numbers, clients of MFIs should be seen as partners. They are constantly engaged. Some MFIs provide institutional structures for clients' participation in the governance and management of the institutions. MFIs should have Branch Councils which are made up of leaders of groups supervised by a Branch Office. Each council should have an elected leader while the Branch Manager serves as secretary. The council meets quarterly to address operations of the branch. Lift Above Poverty Organisation (LAPO) as a case in point.

(v) Charge Real or Market Rates: Since beneficiaries of microfinance are poor, rates of interest should be low or subsidized. However, MFIs have accepted the view that real or market rates be charged to ensure sustainability. The cost of reaching the poor with financial services is enormous. Also, subsidized interest rates connote charity which diminishes the feeling of obligation for repayment. When faced with choices of low interest rates by a transient institution or real rates by a sustainable institution, client would favour the latter (Akintola, 2005)

(vi) Develop Innovative Products: MFIs must recognize that (i) credit needs of clients are diverse and (ii) there are always emerging needs. Credit products should be developed to meet these needs. Clients should be constantly engaged to determine the trends of their requirements. Tested strategies include market research, client exit and satisfaction surveys, and impact monitoring and assessment exercises (Olaikan, 2005).

(vi) Intensive Use of Microfin: A microfin is a powerful automated planning in microfinance. Planning is a key function in any performing MFI. The planning department is charged with task of formulating business plans and short term plans as quarterly and annual plans. The department periodically reviews performance of key indicators as out-reach (Client-base); profitability and portfolio quality. 


\section{CONCLUDING REMARKS}

Robust economic growth cannot be achieved without putting in place well focused programme to reduce poverty through empowering the people by increasing their access to factors of production, especially credit. The latent capacity of the poor for entrepreneurship would be significantly enhanced through the provision of microfinance services to enable them engage in economic activities and be more self-reliant, increase employment opportunity, enhance household income and create wealth.

Unfortunately, from the analysis, it could be observed that most institutions and programmes put in place for this purpose (micro financing) by government and individuals and group of individuals have at best recorded limited success in securing wide access to sustainable micro credit as a critical instrument for growth and poverty reduction. From the impact assessment, it could be observed that most of these institutions and policies and schemes relating to microfinance become moribund few years after initiation due to high operating cost, repayment problem, weak access to re-financing facilities, client apathy and dropout and internal control challenges among others.

With the additional liquidity provided by the recent bank (Microfinance Bank) complemented by the success imperatives suggested in this paper, the microfinance policy objectives would be realized within the ambit of the Millennium Development Goals (MDGs).

\section{REFERENCES}

Adelaja, M. A. 2005. "Understanding the peculiar characteristics of microfinance clients in Nigeria." CBN Proceedings of Seminar In Microfinance Policy, Regulatory and Supervisory Framework for Nigeria.

Attah, J. A. A. and J. Alegieuno. 2005. "Poverty Reduction through Microfinance: The case of Indonesia and Philippines" CBN Bullion, 30(3): 1-10.

Aderibigbe, J. O. 2001. "The Role of the Federal Sector in Poverty Reduction." CBN Bullion, 39(4): 13-24.

Akanji, O. O. 2001. "Microfinance as a Strategy for Poverty Reduction." CBN Bullion, 39(4): 23-34.
Central Bank of Nigeria. 1999. Assessment of the Performance of Nigeria's Rural Financial Institution. A Monograph of Research Dept. of CBN.

Central Bank of Nigeria 2005. Report on Study Tour to India, Pakistan, Indonesia, Philippines and Uganda. Microfinance Policy and Programme Development Committee.

Chigbue, I. N. 2005. "The Challenges of Financing Infrastructure in Nigeria Towards meeting the Millennium Development Goals (MDGs)." $C B N$ Bullion, 30(3): 64-73.

CGAP, 2000. Those Who Leave and Those Who Don't Join. Insights from East African Microfinance Institutions.

Eluhaiwo, P. N. 2005. "Poverty Reduction Through Microfinancing: the case of India." $C B N$ Bullion, 30(3): $42-51$

Enechukwu, I. C. 2005. "Role of Community Banks in Microfinance Intermediation." CBN Proceedings of Seminar in Microfinance Policy, Regulatory and Supervisory Framework for Nigeria.

Godwin Ehigiamusoe 2005. Tested Institutional Practices for Effective Microfinance Services Delivery. Proceedings of seminar in microfinance policy, regulatory and supervisory framework for Nigeria.

Iganiga, B. O. 2006. The Dynamics of the Nigerian Financial System: Products, Process and Reform. Ibadan: Amfitop Books.

Muhota, Kimotho 2005. "National Microfinance policy framework and expected impact on the microfinance market in Nigeria." CBN Proceedings of Seminar in Microfinance Policy, Regulatory and Supervisory Framework for Nigeria.

Magnus, Kpakol 2005. "The role of microfinance in poverty eradication." Proceedings of Seminar in Microfinance Policy, Regulatory and Supervisory Framework for Nigeria.

Ngozi ,Okonji Iweala 2005. "The Role of Government in Microfinance Development in Nigeria." $C B N$ Proceedings of Seminar in Microfinance Policy, Regulatory and Supervisory Framework for Nigeria.

Nnanna, O. J., A. Englama and F. O. Odoko. 2004. Financial Markets in Nigeria. A Central Bank of Nigeria Publication.

Ogbunaka, U. M. 2003. "The Future of Community Banks in Nigeria, Emerging challenges." $C B N$ Bullion, 30(5): 30-41.

Olaitan, M. A. 2005. "Poverty Reduction Through Microfinancing. The case of Pakistan." $C B N$ Bullion, 30(3): 23-41.

Olaitan, M. A. 2001. "Emerging Issues on Micro and Rural Financing in Nigeria." CBN Bullion, 25(1): 45-63.

Shahid, K. 1998. Fighting Poverty with micro-credit: Experience in Bangisdesh. A Monograph of Reseach Dept CBN.

Ukeje, E. U. 2005. "Poverty Reduction Through Microfinancing: the case of Uganda." $C B N$ Bullion, 30(3):30-42. 


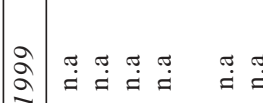

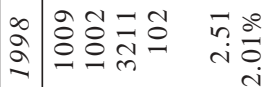

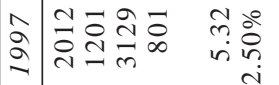

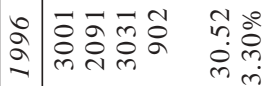

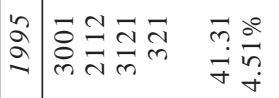

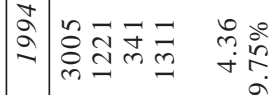

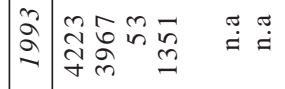

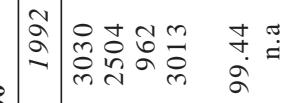
ลั่

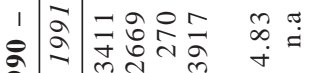
बे ल्रत बे 育

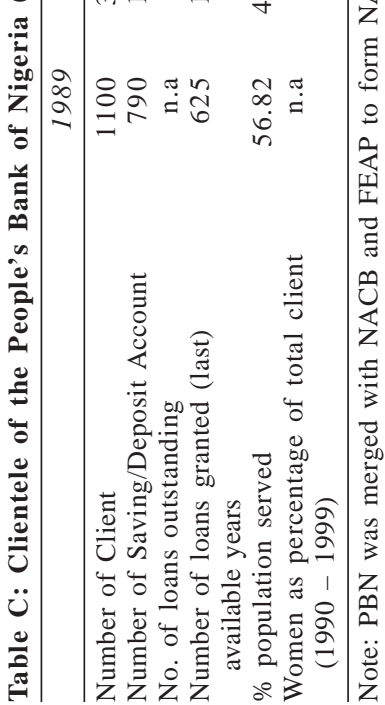



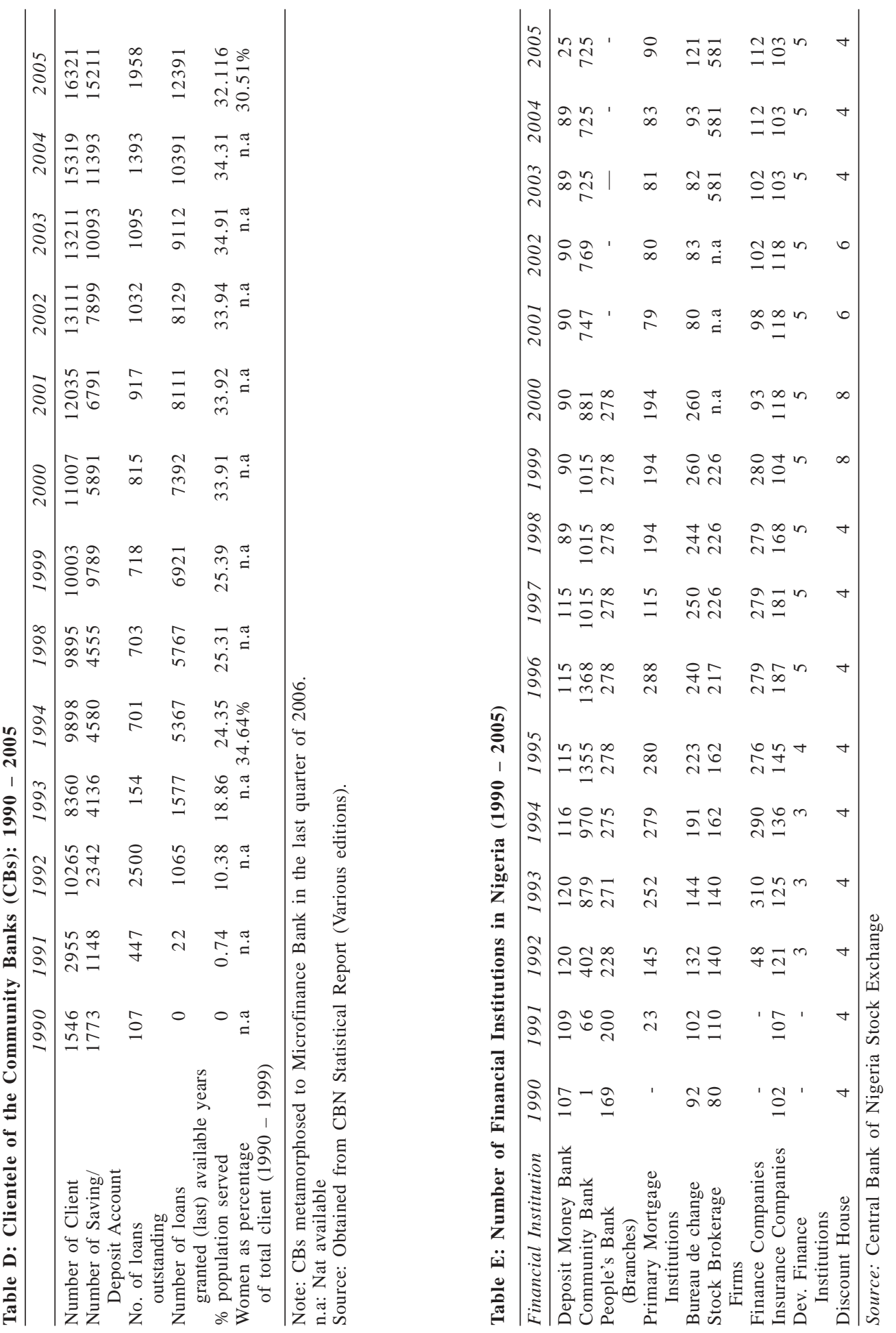